\title{
Criminal Liability for Deaths in Prison Custody: The Corporate Manslaughter and Corporate Homicide Act 2007
}

\author{
DAVID M. DOYLE and SUZANNE SCOTT \\ David M. Doyle is Lecturer in Law, and Suzanne Scott is PhD candidate, \\ Maynooth University, Republic of Ireland
}

\begin{abstract}
This article explores a provision of the Corporate Manslaughter and Corporate Homicide Act 2007, which has been neglected by criminologists and legal scholars - the application of the legislation to deaths in custody. The article argues that proving the liability of a prison based on the definition of 'senior management' in the Act may reflect the problems associated with establishing the guilt of corporate bodies under the common law identification principle and that the 'senior management' test may nullify the intent of Section 2(1)(d) and undermine the capacity of the Crown Prosecution Service (CPS) to convict a prison for an avoidable death in custody.
\end{abstract}

Keywords: corporate manslaughter; custodial deaths; senior management test; corporate liability; identification doctrine; HM Prison Service; public body accountability; gross negligence; prison management structures; duty owed to prisoners

This article will examine the potential liability of HM Prison Service as an organisational body in light of the Corporate Manslaughter and Corporate Homicide Act 2007 (CMCHA 2007) and investigate whether the accountability of the prison service with regard to custodial deaths is extended significantly by Section 2(1)(d) of the statute (Griffin and Moran 2010, pp.358-81). This aspect of the Act was, unsurprisingly, very controversial at the time, given that there were no less than 1,548 prison suicides in the 29 years preceding it (Horder 2012, p.135; Ministry of Justice 2015). The article will argue that the Act's 'senior management' test may reflect the problems associated with establishing the guilt of corporate bodies under the common law identification principle and subsequently undermine the capacity of the Crown Prosecution Service (CPS) to convict a prison for an avoidable death in custody. 


\section{Legislative Background}

David Miers and Alan Page observed, in 1982, that a great deal of the legislation initiated by government has been 'moulded by the unceasing efforts of interest groups who seek to imbue formal legislative initiatives with their own interests and ideas' (Miers and Page 1982, p.56). The Corporate Manslaughter and Corporate Homicide Act of 2007 provides an interesting example of this type of law reform. While concentration on the role of these interest groups alone would, in view of the control which government exercises over access to the legislative process and the preparation of legislation, offer a highly misleading depiction of the legislative process, the influence of cause-centred groups and individuals in the formulation of the 2007 Act cannot be disregarded. The legal reform for which public interest groups, non-governmental organisations (NGOs), and victims' groups began to agitate in the late $1980 \mathrm{~s}$, was provoked by a series of 'accidents' associated with corporate activity - the Clapham Rail disaster, the King's Cross fire, the Piper Alpha oil rig explosion, and most prominently in 1987, the capsize of the Herald of Free Enterprise ferry to name a few - disasters which involved considerable loss of life. The governmental response to each of these tragedies was the establishment of public or legislatively mandated inquiries; however, it soon became apparent that these transportation disasters were not simply the responsibility of a few individuals. Indeed, such inquiries have tended to emphasise the systemic failures in management and accountability, not to mention negligence (or worse), that contributed to these disasters and the consequent loss of life.

Concentration on the overt findings of such inquiries in isolation, however, is potentially misleading. An examination of the rationale underlying the inception of the aforementioned inquiries also discloses a negative side to their establishment. Indeed, there is a temptation to remark of inquiries that they are 'established by government to examine any question for which it cannot find or does not want to find, an immediate solution' (Miers and Page 1982, p.68, italics in original). This procrastination or symbolic aspect cannot be ignored with respect to corporate manslaughter legislation in the UK, particularly when the failings in the law were so evident to see (Almond 2013 , p.25). None of the companies responsible for the above-mentioned disasters were successfully prosecuted for gross negligence manslaughter and in each of these cases, what proved insurmountable was the common law 'identification' doctrine (Matthews 2008, p.9). A company could only be found liable for manslaughter by gross negligence if the fault element of the offence was possessed by someone, such as a director or chief executive, who could be identified as the directing mind and will of the company itself (Horder 2012, p.124). However, the 'identification' doctrine was so restrictive in practice, that there were very few prosecutions and only a limited number of small companies were convicted for gross negligence manslaughter (Ashworth and Horder 2013, pp.153-4).

Yet legislation (even belatedly) stems from 'reactions' (Miers and Page 1982 , p.60). These reactions, whether of political parties, ministers, government departments or individual members of parliament, are directly 
attributable to circumstances, which actors perceive as raising issues or constituting problems, which require legislative action (Miers and Page 1982, p.60). Legislative reactions are also frequently formulated in response to some controversial 'event', public outcry, and media publicity surrounding a particular case, or in response to some unforeseen contingency. The 2007 Act was subject to a lengthy process of critical scrutiny, discussion, and negotiation over a 13-year period, but the application of the legislation to deaths in custody during the final stages of a protracted parliamentary process would certainly have profited greatly from additional consideration. The hasty application of the Act to deaths in custody is largely attributable to the fact that prisoners did not have a powerful interest group (but only a few concerned members of the House of Lords) to agitate on their behalf for legislative reform in this area. Perhaps this is due to the conceptual individualisation and marginalisation of prisoners which 'undermined the development of organized approaches to activism' in respect of victims of workplace violence (Schindeler 2014, p.374).

\section{Section 2(1)(d)}

The statutory offence of corporate manslaughter replaced the common law offence of manslaughter by gross negligence insofar as 'organisations' are concerned (CMCHA 2007, s. 20). The offence does not create any individual liability, although the individuals involved can still be charged with manslaughter - by gross negligence or otherwise - as recently demonstrated by the unsuccessful prosecution of three G4S guards for the 2010 death of Jimmy Mubenga at Heathrow Airport. The legislative framework is, as Ashworth and Horder (2013) note, 'highly technical' (pp.153-4), but for present purposes it suffices to focus primarily on the mechanism by which liability may be imposed on custodial institutions when deaths occur in their care. It was, however, only by reason of a last-minute compromise, that the 2007 Act includes a duty of care to be owed to those detained in custody (Matthews 2008, pp.11-12).

The addition of Section 2(1)(d) resulted from a long and hard campaign in the House of Lords. Although the Bill received cross-party support and passed through the House of Commons relatively quickly, it was delayed for almost five months due to the Lords' insistence of the immediate inclusion in the Act of the duty owed to those persons in custody (Matthews 2008, p.11). The argument advocating for the inclusion of the custody provision was most powerfully enunciated by Lord Hunt of Wirral:

[t]here is no reason why the death of an individual in one situation should be considered less of a death, or less deserving of justice, merely because that situation was presided over by government officials as opposed to privately employed foremen. Indeed, it is all the more of a tragedy and contravention of the natural principle of justice where the state itself acts with such gross negligence that the very lives of its own citizens are forfeit. ${ }^{1}$

The use of the word 'citizens' rather than 'employees' in this particular House of Lords debate was, as Horder notes, 'highly significant', but it was 
also problematic, especially in the custodial context, given that prisoners in England and Wales continue to be deprived of one of the most symbolic manifestation of citizenship - the right to vote - and even more pointedly, because it fails to recognise that a significant number of those who die in State detention are not, in fact, British 'citizens' (Horder 2012, p.115; Singh Bhui 2007, pp.376-7). Yet semantics aside, the argument proffered by Lord Hunt was much more convincing than the government's stance, which sought to justify its opposition to the provision on the basis of cost, risk aversion, and that the existing accountability mechanisms for deaths in custody were sufficient. ${ }^{2}$ Although the majority of the Act was implemented on 6 April 2008, an affirmative order was required to bring section $2(1)(d)$ - which governs the duty of care owed by a custody provider to a person who is detained - into force. This hiatus was designed to furnish custody providers with the requisite time to 'understand fully the extent of these obligations and take steps to implement them'. ${ }^{3}$ The provision was extended to all such custodial institutions on 1 September 2011 (CMCHA 2007 (Commencement No. 3) Order 2011 (SI 2011/1867).

\section{Prison Context}

Scholars have tended to focus on the duty owed by private companies to their employees, almost to the complete exclusion of the duty owed by custodial institutions to those detained. This overlooks the fact that "new capitalism' has impacted upon prison management in a very real way, as it has done upon management structures within the private sector. As Bennett (2015) notes: 'managerialism [within prisons] has evolved in the age of austerity to become more concerned with economy' (p.238), with such evolution having an impact 'on everyday social relations between staff and prisoners and between managers and staff' (p.227).

Yet there are also economic reasons to prevent deaths in custody. A recent study suggests that the financial cost of prison suicide is up to $£ 300$ million per annum (Howard League for Penal Reform 2016). In this context, it seems reasonable to surmise that the real threat of potential criminal sanction would, perhaps, coerce HM Prison Service and the State into investing in preventative measures, which would not only save lives, but also be more cost-effective. Failing to cast the academic lens over the public sector more broadly, and over the carceral sector more specifically, prevents any meaningful comparative analysis from being conducted in this important area of law and policy.

The fact that the application of the 2007 Act to the 'ugly side of public service activity' has not been subject to much academic scrutiny (Horder 2012, p.115) is particularly evident in the prison context, where there has been a considerable number of reports over the last decade that have repeatedly offered evidence of inadequate screening and formal risk assessment, not to mention insufficient and inexperienced staffing, overcrowded conditions, and recurrent weaknesses in the implementation of the prison service suicide and self-harm prevention procedures (as set out in Safer Custody, Prison Service Instruction (PSI) 64/2011 (Ministry of 
Justice 2011) and in the Assessment, Care in Custody and Teamwork (ACCT) Plan, version 5) (Prisons and Probation Ombudsman 2014a, p.5; HM Chief Inspector of Prisons for England and Wales 2014, p.29). Furthermore, there is evidence - despite the effect of deaths in custody on both the individuals and establishments involved (Liebling 2002, pp.201-2) - that certain prisons still fail to give sufficient attention to implementing and reinforcing the recommendations of the Prisons and Probation Ombudsman (PPO), who investigates all deaths in prison custody, in fulfilment of the procedural duty under Article 2 of the European Convention of Human Rights (ECHR) (Owers 2009, p.1537).

Prisoners endure the effects of both individual and institutional failings in HM Prison Service - the unacceptable risk of violence and victimisation, and 'personal crisis and utter despair' (Prisons and Probation Ombudsman 2014a, p.5), and who, in consequence, are taking their own lives in considerable numbers (Horder 2012, p.115). True, prisons are 'inevitably dangerous' places but grasping the nature of prison life requires that lethal violence be defined beyond the ordinary sense of a fatal stabbing or beating (Foster 2005, p.81). The means by which prisoners die in custody vary across a spectrum of medical, legal, and illegal concerns: from State sanctions like judicial execution, to diseases like tuberculosis; from 'accidents' to sudden heart attacks; from homicides to suicides and hunger strikes. Some are recorded as 'natural' deaths by prison authorities, others as 'unnatural' (suicides, homicides, State-sponsored executions or 'accidental' work-related deaths), but the line between these kinds of death is not always clear, and decisions as to where it is drawn are subjective (Blue 2012, pp.189-90). As Ethan Blue (2012) pointed out, the line between State-sanctioned punishment and self-destruction (whether intended or not) is blurred in the modern prison, and scholars have too frequently 'misunderstood these deathways as analytically and politically distinct' (p.190).

Indeed, as Horder (2012) has argued, a prisoner is almost entirely dependent on the respective prison to safeguard his or her health and safety during what may be a lengthy, or an indeterminate, sentence and that this should supersede the 'countervailing considerations and warrants of placing the relevant organisation under an ongoing duty of care' (p.137). This argument was perfectly encapsulated by Lord Hunt who asserted that:

The power lawfully to deprive an individual of his or her liberty must be one of the most serious responsibilities there can be. The duty of care owed to an individual in detention, where he cannot act freely in his own interests, is onerous and profound. ${ }^{4}$

In this regard, it is also important to point out that the House of Lords in the case of ex parte Amin ([2003] UKHL 51) (the Zahid Mubarek case), was unanimous in rejecting the government's argument, successful before the Court of Appeal, that 'an allegation of negligence leading to death in custody, though grave enough in all conscience, bears a different quality from a case where it is said that the state has laid on lethal hands' and held that systemic failures leading to deaths called for even greater scrutiny (para. 50). Lord Bingham, for instance, said 'a systemic failure to protect 
the lives of persons detained may well call for even more anxious consideration and raise even more intractable problems' (para. 21).

The clamour to ensure the applicability of the 2007 Act to the prison service and other 'carceral' spaces can, however, only be properly understood when one places the number of custodial deaths in comparative perspective. For instance, there were 150 deaths among British workers (almost all of which occurred in the pursuit of private corporate activity) between April 2012 and March 2013 (Health and Safety Executive (HSE) 2015 , p.10). By contrast, there were 181 deaths in prison custody in the same period, 52 of which were classified as 'self-inflicted' (Ministry of Justice 2014, p.7). Thus, to put it another way, prisoners in this period were more likely to take their own lives than construction employees were to be killed at work (there were 46 fatal injuries in the construction industry in the twelve months from 1 April 2013 to 31 March 2014).

Crucially, research has shown that self-inflicted deaths in prison custody are inextricably linked to 'incidents' of self-harm. According to the findings of one systematic review of the risk factors of suicide in prisoners, approximately $50 \%$ of people who die by suicide in prison have a history of self-harm, which increases the odds of suicide in custody between six and eleven times (Fazel et al. 2008, p.1721). A more recent study in The Lancet also observed that there were 139,195 recorded self-harm incidents involving 26,510 prisoners between January 2004 and December 2009 (Hawton et al. 2014, pp.1147-54). Although most incidents were of a low lethality, 109 suicides (411 per 100,000 average annual prison population) were recorded among the 26,510 individuals who had self-harmed over this six-year period, and more than half the deaths occurred within a month of the self-harm (Hawton et al. 2014, p.1151). The authors drew attention, among other things, to the necessity of raising staff awareness, further training, and the initiation of measures to identify individuals at risk at reception, and to ensure that appropriate preventative measures are instigated (Hawton et al. 2014, p.1152). They also concluded that a 'major challenge is [the] negative attitudes of prison officers and health-care staff' and that addressing these 'beliefs should be part of any self-harm strategy' (p.1153). Of course, this is not a recent phenomenon. A study of prison suicides between 1999 and 2000, conducted as part of the National Confidential Inquiry in Suicides and Homicides by Mentally Ill People, revealed that '[o]ne in six self-inflicted deaths (17\%) were among inpatients in the prison healthcare centre at the time of death, and $15 \%$ of suicides were seen by health staff as preventable with closer supervision, better training, and an increased use of shared cells' (House of Lords, House of Commons, Joint Committee on Human Rights 2004, p.21; Shaw, Appleby and Baker 1999).

Regrettably, these are not the only examples of ineffective management in custodial institutions or of poor support from staff of detainees at risk of suicide or self-harm (Prisons and Probation Ombudsman 2014a, p.9, 2015 , p.6). In this respect, one need barely look further than the murder of Zahid Mubarek, who was killed by his cellmate, Robert Stewart, at Feltham Young Offender Institution (YOI) in March 2000. Stewart had 
been 'manifesting extreme racist views in correspondence, and was diagnosed during the criminal proceedings as a psychopath' (Keith 2006, p.6). His previous prison history had been marred by 'violent and disruptive behaviour' and this led to the conclusion, on more than one occasion, that he was a 'disaster waiting to happen' (Keith 2006, p.123). On arrival at Feltham, Stewart was placed in a cell with Mubarek and brutally attacked him with a wooden table leg. An inquiry into the murder conducted by a senior prison service investigating officer, Mr Ted Butt, concluded that Feltham was 'institutionally racist' at the time of the death - a finding subsequently reaffirmed by an investigation into racial discrimination within the prison service, conducted by the Committee for Racial Equality (CRE). These investigations were, however, deemed by the House of Lords to be insufficient to meet with the UK's obligations under Articles 1 and 2(1) of the ECHR and a public inquiry chaired by Mr Justice Keith ensued, which asserted that acts of violence 'are more likely to occur in prisons which are performing badly', which includes those prisons with systemic and institutional failings (Keith 2006, p.650).

Remarkably, the report also noted that the governor given line management responsibility had 'very little operational experience', and did not get the requisite support from the manager of the department, "who had become complacent as his retirement beckoned' (Keith 2006, pp.637, 610). The systemic failings of the prison service in this regard was also reiterated by Deborah Coles in the context of female deaths in custody:

[t]he failure to provide adequate and appropriate care once in prison heavily contributed to their deaths. For example, drug withdrawals and detoxifications were poorly managed and framed in the context of punishment rather than care, symptoms of mental illness were too often responded to with discipline, and women on suicide watch were not adequately observed. In many cases, there were numerous failures in the treatment and care provided to an individual woman. (Coles 2013, p.43, italics in original)

Six years on from the Corston Report (Corston 2007) - which was triggered by the self-inflicted deaths of six women at HMP Styal in a twelve-month period between 2002 and 2003 - Coles (2013) concluded that the resulting changes have been merely 'cosmetic' and a 'tinkering at the periphery of a deeply flawed system' (p.50). It is difficult to disagree with her assessment.

\section{Corporate Manslaughter and Public Bodies}

Corporate manslaughter is not the only way through which a public body can be held accountable for the death of a prisoner in the UK. Under Sections 7(1)(a) and 8 of the Human Rights Act 1998, a deceased prisoner's family may pursue a civil claim in his name 'in respect of his ill-treatment and death in custody', provided the deceased was aged over 18 years at the time of his death (Livingstone, Owen and Macdonald 2015, p.132). Complaint mechanisms also exist in international law; close relatives of a deceased prisoner can take a claim against the State under Article 34 of the ECHR for an alleged breach of Articles 2 and 3 of the ECHR, for example. 
However, these are avenues of civil redress and are, therefore, rooted in the individual harm caused as opposed to the harm caused to society as a whole, the latter constituting a crime.

By virtue of Schedule 1, the offence of 'Corporate Manslaughter' not only applies to private companies but also in 'some measure to all the public bodies the performance of whose functions are most likely to involve causing deaths' (Horder 2012, p.117). These include, inter alia, the Ministry of Defence, the Department of Health, and HM Prison Service. Section 2(2) of the Act provides that a duty of care is owed to anyone who is detained at a custodial institution such as a prison, a young offender institution/secure training centre, a juvenile justice centre or a remand centre; or in a custody area at a court or a police station (CMCHA 2007, s. 2(2)). The Act also covers duties of care owed to those detained at immigration removal centres or short-term holding facilities, those who are being transported in a vehicle as a result of prison or immigration escort arrangements, those who have been placed in secure accommodation, and those who are detained in any premises under the Mental Health Act 1983. Yet, although the 2007 Act defines the scope of the duty, the nature of the duty is simply described as the duty owed under the law of negligence by the organisation to 'someone for whose safety the organisation is responsible' (CMCHA 2007, s. 2(1)(d)). Although it is well established in the law of tort that an organisation responsible for the detention of a person owes that person a duty to take reasonable care in respect of that person's health and safety, conjecture remains with regard to the exact extent of that duty (Matthews 2008, p.66). Thus far, there has been no judicial consideration of the scope of the duty of care to prevent prisoner deaths at the hands of other prisoners, but the courts have held, in respect of self-inflicted deaths, that the duty to take reasonable care encompasses a duty to take reasonable steps to prevent a person from committing suicide, but only where the custodians knew or ought to have known that the individual prisoner was a suicide risk (p.66). The Court of Appeal in Orange v. Chief Constable of West Yorkshire Police ([2002] QB 347) did state, however, that, given the increased risk of suicide among prisoners, there was an obligation to take reasonable steps to identify whether or not a prisoner presented a suicide risk (para. 43). These decisions would suggest that the 2007 Act may only be applicable where the prisoner was being monitored under the prison service suicide and self-harm prevention procedures at the time of their self-inflicted death, or where appropriate measures had not been taken to identify the known risk factors or 'triggers' (Prisons and Probation Ombudsman 2014b).

What is clearer, however, is that the offence is committed only if the death is caused by the way in which the custodial institution's activities are managed and organised by its senior management and this must be a 'substantial element' in the gross breach of a relevant duty of care to the deceased. 'Senior management' is defined in the 2007 Act as persons who play significant roles in 'the making of decisions about how the whole or a substantial part of its activities' or the 'actual managing and organising of the whole or a substantial part of those activities' (CMCHA 2007, s. 1(4)(c)). The first limb of this definition is, as Griffin and Moran (2010) observe, 
a 'reflection of common law 'directing mind' test', but the 'second part of the definition removes any requirement on the part of a senior manager to possess a directing influence in the organisation or management of a relevant organisation's activities and policies' (p.370). Accordingly, it would appear that the liability of a prison 'may now ensue without the necessity of establishing that a senior manager obeyed policy or instructions dictated by the organisation's directing mind' (p.370). In other words, the prison service could potentially be prosecuted for manslaughter if gross failures of senior management cause the death of a prisoner. Liability, however, appears to be excluded where the death is due to a public policy decision not to allocate appropriate resources to the prison service (CMCHA 2007, s. 3(1)). Thus, as Horder (2012) has written:

... a decision not to use limited resources to build more prison accommodation, with the result that prisoners must share cells because there is no other way of accommodating rising numbers, could not, in and of itself, give rise to liability for (say) a consequent suicide, even if that decision reflected glaring failures of strategic planning. On the other hand, management bungling that led to a decision to make two particular prisoners share a cell, with the entirely foreseeable result that one killed the other would ... be covered by section 2(1)(d). (pp.131-2)

The common law identification principle is also reformed further by virtue of the fact that an organisation's liability may now also be established by 'aggregating the cumulative conduct of a collective of senior managers' (Griffin and Moran 2010, p.370). Although the concept of aggregation was rejected by the trial court in $R$ v. PEO Ferries ([1991] 93 Cr. App. R. 72), the 2007 Act appears to accept aggregated fault in a limited form and makes it possible to convict a prison on the basis of collective failings that must include, but are not restricted to, failings on the part of senior managers. Take, for example, the murder of Zahid Mubarek. Had Feltham YOI been prosecuted for the death of Zahid Mubarek under the 2007 Act (had it been in force at the time) it is reasonable to assume that the case would have succeeded.

Section 8 of the Act also stipulates that juries must consider any evidence that shows an alleged breach of health and safety legislation. This may have important consequences, since the Health and Safety at Work Act 1974 is largely inapplicable in prisons and cannot be invoked by prisoners who suffer breaches of it, even though Standing Order 6A (15) allows for prison inspections by the Health and Safety Executive and HM Prison Service has been censured four times since 1999 (Livingstone et al. 2008, p.232). This is also significant in that the Act states that, should a violation of health and safety legislation be established, juries are permitted to take into account whether 'attitudes, policies, systems or accepted practices within the organisation' were likely to have encouraged any failure to meet safety standards or produced a tolerance of it (CMCHA 2007, s. 8(3)). Perhaps a crown censure would be sufficient evidence to show that HM Prison Service failed to comply with health and safety legislation, but evidence of a prison's culture and ethos may be decisive in certain cases involving deaths in custody (Ex Parte Amin, para. 26). It seems reasonable to surmise, however, that the 
test set out in Section 1 - which forces 'the inquiry back onto the issue of identifiable individuals' (Ormerod and Taylor 2008, p.604) - is more likely to prove restrictive than Section 8 in practice (Almond 2013, p.31).

\section{Senior Management}

There are three levels of management in HM Prison Service since the introduction of the new Fair and Sustainable working structures on 1 April 2013. The first-tier definition of senior management (in effect the 'directing mind' of the prison) consists solely of the office of prison governor, a position which has undergone significant transformation in recent years, becoming increasingly managerial in nature (Bryans 2013, p.3). One of the consequences of the shift towards managerialism is the reliance of governors 'on senior managers and intermediate management to ensure the implementation and delivery of all policies' (p.62). Indeed, the most recent group profiles for Governing Governors at both Standard and Complex Establishments encapsulate this approach. At an organisational level, Governing Governors are 'Senior Management' and accountable for the 'provision of leadership, direction, coordination, strategic decisions and risks for a large/complex establishment with managerial responsibility for all staff across their functions' (National Offender Management Service 2013a, 2013b). They also have responsibility for 'the budgets allocated to functions and the effective and efficient use of resources to ensure the security of establishment' (National Offender Management Service 2013a, 2013b). Although these are 'operational and prisoner-facing roles', the typical tasks associated with this group profile appear to place particular emphasis on policy orientation, performance, and strategic planning (National Offender Management Service 2013a, 2013b). Indeed, as one governor put it: 'I see my role as a strategic one, it is about direction and planning not about the day-to-day operations' (Bryans 2013, p.150).

For this reason, the selection of the Senior Management Team (SMT) is of 'paramount importance' (Bryans 2013, p.187). 'Governors', as Lord Keith (2006) observed in the Report of the Zahid Mubarek Inquiry, 'have to rely on their senior management team for many things' (p.342). The Governing Governor may, of course, delegate responsibility for overseeing the daily operations of the prison to the Deputy Governor in order to focus on strategic issues, but even the group profiles for deputy posts tend to accentuate policy matters, strategic planning, and the implementation of corporate activities rather than day-to-day operations (National Offender Management Service 2013c, 2013d). The second tier of management within HM Prison Service also comprises Head of Functions (some of these positions are non-operational). A Head of Function (Band 8) will not line manage a Head of Function (Band 7), but they do have line management responsibility for custodial managers and they, too, need to 'ensure that they implement robust systems to manage the function, as they will often be distanced from front-line activity duties and will need to delegate appropriately' (National Offender Management Service 2013e, 2013f). 
Once appointed, Head of Functions are usually matched with a specific job description and such designations include responsibility for safer custody. For example, at the end of December 2014, there were approximately 60 Head of Functions: Residence and Safety and 50 Head of Functions: Safer Prisons and Equality, whose responsibility encompassed, inter alia, ensuring that prisoners were cared for in a safe, decent, lawful, and secure manner. Such Head of Functions have a variety of functions in terms of safer custody, which includes accountability for the establishment of suicide, self-harm, and violence reduction strategies; organising Death in Custody (DIC) Investigations and ensuring that the PPO receives all the relevant information and assistance; ensuring that all statistics and trends in relation to safer custody are monitored and acted upon; conducting quality assurance processes with respect to the use of force; managing the cell-sharing risk assessment database; and carrying out briefings on ACCT (National Offender Management Service 2013g). The SMT within a prison is, thus, composed of members from both management tiers: Governors (first tier) and Deputy Governors and frequently Head of Functions (second tier). Although the exact composition of the SMT varies according to the complexity of the establishment, proving a prison's liability based on the definition of 'senior management' in the 2007 Act may, in fact, 'mirror the difficulties' associated with establishing guilt of corporate bodies under the common law identification principle (Griffin and Moran 2010, p.371).

Indeed, it seems plausible to argue that the 'senior management' test renders Section 2(1)(d) somewhat ineffective, because it fails to acknowledge both the reality of how the suicide and self-harm prevention procedures work in UK prisons and the complexity of the organisational structure within HM Prison Service. An ACCT plan must be opened by any prison staff member who 'receives information ... or observes behaviour which may indicate a risk of suicide/self-harm' (PSI 64/2011). Within an hour of the ACCT being opened, the relevant manager must talk to the prisoner and complete the Immediate Action Plan (IAP) to ensure that the prisoner is safe from harm; arrange for an ACCT assessment to take place; and organise the first Case Review (Livingstone, Owen and Macdonald 2015, p.314). The person conducting the ACCT assessment must interview the at-risk prisoner within 24 hours of the opening of the ACCT and the first Case Review must take place within the next 24 hours. A CAREMAP, which gives 'detailed and time-bound actions aimed at reducing the suicide or self-harm risk', is to be completed by the relevant manager (p.314).

Thus, it is the custodial manager - who has line management responsibilities for supervising/specialist officers, prison officers, and operational support grades - who, at least according to PSI 64/2011 and ACCT document (v.5), bears primary responsibility for Case Reviews and the day-to-day management of the ACCT Plan. But in practice, it appears that in the more straightforward cases it is a supervisory/specialist officer or a prison officer - who have no line management responsibilities whatsoever - who often assume practical responsibility for the ACCT process, including ensuring that the specified conversations and observations 
take place, and implementing the requisite measures to negate the risk in accordance with Safer Custody procedures. Indeed, it seems that in certain prisons it is only in the more complex cases, perhaps where an enhanced Case Review is required, that custodial managers are actually involved in the day-to-day management of ACCT. Accordingly, it is submitted that the actual management control of the procedures to prevent deaths in custody, at least in the prison context, are exercised, in practice, at a non-managerial level, and it is difficult to envisage how a supervising/specialist or a prison officer - exercising the role of 'Care Manager' within the ACCT process - could meet the criteria specified in the CMCHA 2007 in terms of 'senior management'. Indeed, even in the occasional instances where management is involved in the ACCT process, it is at the level of first-line or third-tier management and a custodial manager - a 'uniformed role' (National Offender Management Service 2012, p.8) - and this would certainly not be classed as senior management within HM Prison Service. In order to enable the CPS to establish a prison's liability for a death in a custodial setting in these circumstances, a custodial manager would have to be identified as a senior manager and involved in the ACCT process. This, of course, not only appears 'unduly restrictive' and 'threatens to open the door to endless argument in court as to whether certain persons do or do not constitute senior managers' (Clarkson 2005, p.683), but it would also mean completely ignoring the practical reality of the organisational hierarchy and the suicide prevention strategies within HM Prison Service.

Furthermore, in its concentration on 'senior management', the Act fails to take account of the individual failings of a wider range of individuals within the organisation. Various inquests, thematic reviews, and Chief Coroner Reports to Prevent Deaths (previously Rule 43 reports) reveal that a substantial number of avoidable deaths in custody can be attributed to failures by lower-ranking staff to properly implement the correct policies and procedures where a prisoner has been identified as at risk. Of course, it could be argued that senior management must issue rules and guidance to staff, both orally and in writing, and that weaknesses in the implementation of the death avoidance procedures are, at least partially, attributable to a failure on the part of senior management to subject the processes to rigorous checks, but it should also be borne in mind that any case of corporate manslaughter must rest, as a prerequisite for success, on proof of a breach of a duty of care on the part of senior managers and that the senior management failure must be a substantial element in the breach of that duty. The term 'substantial element' is not defined by the Act of 2007 but rather a question of fact for the jury who must determine, as a matter of causation, whether the culpability of a senior manager was more than minimal, 'albeit not necessarily an absolute factor, in the breach of duty resulting in a person's death' (Griffin and Moran 2010, p.370). Therefore, other than in an unusual situation where a death in prison was directly attributable to a direction or instruction given by a Governor, a Deputy Governor or a Head of Function ('something that is not usual during standard ACCT procedures' (Prisons and Probation Ombudsman 2014a, p.19)), it would be very difficult for the CPS to establish a prison's liability for the offence of 
corporate manslaughter, and even where a custodial manager is involved in the ACCT process, the difficulty in identifying a line manager as senior management may nullify the intent of Section 2(1)(d) and undermine the capacity of the Crown to successfully convict a prison for an avoidable death in custody. Similarly, the Crown may face difficulties in attempting to convict a police force for the death of a person within its custody because it is hard to see how a custody officer, a 'lowly ranking' role, albeit one which 'plays a significant role in actually managing or organising a substantial part of a police force's activities', could be identified as a senior manager (Griffin and Moran 2010, p.376).

\section{Conclusion}

In conclusion, there are other aspects of which to be critical in the 2007 statute as originally enacted, including its exclusive focus on organisational liability, its extension to such a diverse array of organisations, the exemptions to police officers and army officials, and the requirement of Director of Public Prosecutions (DPP) consent to prosecute. Other, more appropriate, types of criminal legislation than the law of corporate manslaughter might be constructed to cover these types of situations (Gobert 2008, pp.415-16). The new approach also provokes the broader question of whether it is the conviction of companies and public bodies that is the most significant facet, or whether the punishment of organisations should be considered as important, too (Ashworth and Horder 2013, p.154). A custodial institution can hardly be imprisoned, moderate fines can be swallowed up as operational costs, and severe fines may result in further reductions in the number of prison officers which would inevitably have deleterious effects on the safety and welfare of inmates. Finally, there is also some evidence, at least in a custodial context, to suggest that perhaps the Act should have been extended beyond the limited (but high-profile) area of homicide (Gobert 2008, pp.419-22). Take, for instance, the remarks of Lord Ramsbotham, when speaking of Wormwood Scrubs during a debate on the Bill. Although observing that there was 'no case of manslaughter', he recalled that 'there was extraordinarily bad behaviour by staff, brutality of prisoners and, over a number of years, management failure on a scale that [he] simply could not believe'. ${ }^{5}$

The symbolic significance of the 2007 Act may 'ultimately transcend its methodological deficiencies' and the primary value of the Act may very well lie in the very fact of its existence (Gobert 2008, p.413). If nothing else, it was anticipated that the Act would, at least, spur the prison service and a variety of other custodial institutions to satisfy themselves that the structures and systems for preventing deaths in custody were fit for purpose and coerce them to take a fresh look at their culture and ethos in this regard (Gobert 2008, pp.425-32). Furthermore, it was envisaged that the Section 2(1)(d) duty would encourage the prison service to afford greater compliance with safer custody practices as embodied in PSI 64/2011 and the ACCT document (v.5). As Lord Ramsbotham put it: 
I seriously believe that the Bill would energise the management system in a way that nothing else that I have come across in the past 10 years seems to have been able to. ${ }^{6}$

Yet despite such optimistic pronouncements, there were more self-inflicted deaths in prison custody in 2014 than at any time in the last ten years 'reversing a downturn in the previous decade' (HM Chief Inspector of Prisons for England and Wales 2014, p.25). Indeed, '[s]uicide remains the highest cause of death in prisons' (Livingstone, Owen and Macdonald 2015, p.308), its pervasiveness having been linked to the prevalence of mental health issues within prisons (Prison Reform Trust 2015, p.7). Despite this increase, the Corporate Manslaughter Act has not yet been invoked for a single death in prison custody, or, for that matter, a fatality in any other complex large-scale organisation in the public or private sector. It also appears that, even if proceedings were instituted against a prison for a death in custody, judicial interpretation of Section 2(1)(d) and, more particularly, the senior management test, may prove evidentially problematic. Although the management of a prison will ultimately fall under the rubric of the SMT, the death avoidance and ACCT procedures are implemented, at best, at line management level and invariably at a non-managerial level. While, of course, it may be a rational supposition for a jury, in determining the liability of a prison, to conclude that the responsibility for the breach of a relevant duty should logically be attributed to members of the SMT, it should be borne in mind that an 'ability to deflect liability may reside in any large organisation that is characterised by a system of complex management structures' (Griffin and Moran 2010, p.371). For instance, although a failure at first line management may give rise to an expectation that say a Head of Function Standard Complex: Safer Prisons and Equality as a member of the SMT failed to ensure that suicide, self-harm and violence reduction strategies were implemented by custodial managers, that failure may be deemed to be only a contributory element in the breach of the duty. If the senior management failure is but a contributory factor, the liability of the prison may not ensue given that the management failure must, in accordance with Section 3, be a substantial element in the gross breach of the relevant duty of care (p.371). Of course, the ability to deflect responsibility has always been, and still is, at least in the prison context, a major limitation on liability, and like its predecessor the 'identification' principle did with medium- to large-size corporate bodies, it fails to take into account that crucial strategic and more importantly, operational, decisions, are frequently not only delegated but assigned to lower levels of management and operations than those granted policy authority over the prison's affairs (p.371). Both independent and anecdotal evidence suggests that this is certainly the case with Safer Custody. It is, nonetheless, unacceptable that a prison could be able to escape liability for a completely avoidable death in custody, especially when the fault element for the crime was possessed by a custodial manager or a prison officer who had authority to take operational decisions, simply because that person was not a member of the SMT. Death and incarceration remain within close proximity to one another and prisoners continue to maintain 'an intimacy 
with death' (Blue 2012, p.189). Nevertheless, accountability for avoidable deaths in prisons should be ensured and at least the 2007 Act makes some progress towards ensuring such accountability, even if only symbolically.

\section{Notes}

1 Hansard, HL Debates, 5th series, vol. 688, part 26, col. GC 189, 15 January 2007. Available at: http://www.publications.parliament.uk/pa/ld200607/ldhansrd/text/70115-gc0003.htm (accessed 26 May 2015).

2 Hansard, HC Debates, 5th series, vol. 460, part 91, col. 664, 16 May 2007. Available at: http://www.publications.parliament.uk/pa/cm200607/cmhansrd/cm070516/debtext/ 70516-0011.htm\#07051687001914 (accessed 26 May 2015).

3 Hansard, HC Debates, 5th series, vol. 463, part 126, col. 333, 18 July 2007. Available at: http://www.publications.parliament.uk/pa/cm200607/cmhansrd/cm070718/debtext/ 70718-0012.htm\#07071867002951 (accessed 26 May 2015).

4 Hansard, HL Debates, 5th series, vol. 688, part 26, col. GC 186, 15 January 2007. Available at: http://www.publications.parliament.uk/pa/ld200607/ldhansrd/text/ 70115-gc0003.htm (accessed 26 May 2015).

5 Hansard, HL Debates, 5th series, vol. 688, part 26, col. GC 192, 15 January 2007. Available at: http://www.publications.parliament.uk/pa/ld200607/ldhansrd/text/70115-gc0004.htm (accessed 24 May 2016).

6 Hansard, HL Debates, 5th series, vol. 688, part 26, col. GC 193, 15 January 2007. Available at: http://www.publications.parliament.uk/pa/ld200607/ldhansrd/text/70115-gc0004.htm (accessed 24 May 2016).

\section{References}

Almond, P. (2013) Corporate Manslaughter and Regulatory Reform, Basingstoke: Palgrave Macmillan.

Ashworth, A. and Horder, J. (2013) Principles of Criminal Law, 7th edn, Oxford: Oxford University Press.

Bennett, J. (2015) The Working Lives of Prison Managers: Global Change, Local Culture and Individual Agency in the Late Modern Prison, Basingstoke: Palgrave Macmillan.

Blue, E. (2012) Doing Time in the Depression: Everyday Life in Texas and California Prisons, New York, NY.: New York University Press.

Bryans, S. (2013) Prison Governors, Cullompton: Willan.

Clarkson, C. (2005) 'Corporate manslaughter: yet more government proposals', Criminal Law Review, 9, 677-89.

Coles, D. (2013) 'Deaths of women in prison: the human rights issues arising', in: M. Malloch and G. McIvor (Eds.), Women, Punishment and Social Justice: Human Rights and Penal Practices, London: Routledge.

Corston, J. (2007) The Corston Report: A Report of a Review of Women with Particular Vulnerabilities in the Criminal Justice System, London: Home Office.

Fazel, S., Cartwright, J., Norman-Nott, A. and Hawton, K. (2008) 'Suicide in prisoners: a systematic review of risk factors', Journal of Clinical Psychiatry, 69, 1721-31.

Foster, S. (2005) 'The negligence of prison authorities and the protection of prisoner's rights', Liverpool Law Review, 26, 75-99.

Gobert, J. (2008) 'The Corporate Manslaughter and Corporate Homicide Act 2007 thirteen years in the making but was it worth the wait?', Modern Law Review, 71, 413-33.

Griffin, S. and Moran, J. (2010) 'Accountability for deaths attributable to the gross negligent act or omission of a police force', Journal of Criminal Law, 74, 358-81. 
Hawton, K., Linsell, L., Adeniji, T., Sariaslan, A. and Fazel, S. (2014) 'Self-harm in prisons in England and Wales: an epidemiological study of prevalence, risk factors, clustering, and subsequent suicide', The Lancet, 383, 1147-54.

Health and Safety Executive (HSE) (2015) Statistics on Fatal Injuries in the Workplace in Great Britain 2015. Available at: http://www.hse.gov.uk/statistics/pdf/fatalinjuries.pdf (accessed 9 February 2016).

HM Chief Inspector of Prisons for England and Wales (2014) Annual Report 2013-14, London: The Stationery Office. Available at: https://www.justiceinspectorates.gov.uk/ hmiprisons/wp-content/uploads/sites/4/2014/10/HMIP-AR_2013-14.pdf (accessed 26 May 2015).

Horder, J. (2012) Homicide and the Politics of Law Reform, Oxford: Oxford University Press. House of Lords, House of Commons, Joint Committee on Human Rights (2004) Deaths in Custody, Third Report of Session 2004-05, Vol. II: Oral and Written Evidence, HL 15-II/HC 137-II, London: The Stationery Office. Available at: http://www.publications.parliament.uk/pa/jt200405/jtselect/jtrights/15/15ii.pdf (accessed 21 May 2016).

Howard League for Penal Reform (2016) The Cost of Prison Suicide. Available at: https:// d19ylpo4aovc7m.cloudfront.net/fileadmin/howard_league/user/pdf/Publications/

The_cost_of_prison_suicide.pdf (accessed 14 March 2016).

Keith, B. (2006) Report of the Zahid Mubarek Inquiry, London: The Stationery Office.

Liebling, A. (2002) Suicides in Prison, London: Routledge.

Livingstone, S., Owen, T., Macdonald, A., Ní Ghrálaigh, B. and Law, H. (2008) Prison Law, Oxford: Oxford University Press.

Livingstone, S., Owen, T. and Macdonald, A. (2015) Livingstone, Owen, and Macdonald on Prison Law, Oxford: Oxford University Press.

Matthews, R. (2008) Blackstone's Guide to the Corporate Manslaughter and Corporate Homicide Act 2007, Oxford: Oxford University Press.

Miers, D.R. and Page, A.C. (1982) Legislation, London: Sweet \& Maxwell.

Ministry of Justice (2011) Management of Prisoners at Risk of Harm to Self, to Others and from Others (Safer Custody), Prison Service Instruction (PSI) 64/2011, London: Ministry of Justice.

Ministry of Justice (2014) Safety in Custody Statistics England and Wales Update to March 2014. Available at: https://www.gov.uk/government/uploads/system/uploads/attachment_ data/file/339067/safety-in-custody-to-mar-2014.pdf (accessed 26 May 2015).

Ministry of Justice (2015) Deaths in Prison Custody. Available at: https://www.gov.uk/government/statistics/safety-in-custody-quarterly-update-to-december-2014-and-annual (accessed 26 May 2015).

National Offender Management Service (2012) Fair and Sustainable: Revision to Proposals for Working Structures in HM Prison Service following the Consultation with Trade Unions, London: Ministry of Justice.

National Offender Management Service (2013a) Group Profile: Governing Governor - Standard Establishment (FOI 94988), London: Ministry of Justice.

National Offender Management Service (2013b) Group Profile: Governing Governor - Complex Establishment (FOI 94988), London: Ministry of Justice.

National Offender Management Service (2013c) Group Profile: Deputy Governor - Complex Establishment (FOI 94988), London: Ministry of Justice.

National Offender Management Service (2013d) Group Profile: Deputy Governor with Function (FOI 94988), London: Ministry of Justice.

National Offender Management Service (2013e) Head of Function Operational - Complex Establishment (FOI 94988), London: Ministry of Justice.

National Offender Management Service (2013f) Group Profile: Head of Function Operational - Standard Establishment (FOI 94988), London: Ministry of Justice. 
National Offender Management Service (2013g) Job Description. HOFSC: Safer Prisons and Equality (FOI 94988), London: Ministry of Justice.

Ormerod, D. and Taylor, R. (2008) 'The Corporate Manslaughter and Corporate Homicide Act 2007', Criminal Law Review, 8, 589-611.

Owers, A. (2009) 'Prison inspection and the protection of prisoners' rights', Pace Law Review, 30, 1535-47.

Prison Reform Trust (2015) Prison: The Facts. Available at: http://www.prisonreformtrust.org. uk/Portals/0/Documents/Prison\%20the\%20facts\%20May\%202015.pdf (accessed 14 March 2016).

Prisons and Probation Ombudsman (2014a) Learning from PPO Investigations: Self-inflicted Deaths of Prisoners on ACCT. Available at: http://www.ppo.gov.uk/wpcontent/uploads/ 2014/07/ACCT_thematic_final_web.pdf (accessed 26 May 2015).

Prisons and Probation Ombudsman (2014b) Learning from PPO Investigations: Risk Factors in Self-inflicted Deaths in Prisons. Available at: http://www.ppo.gov.uk/wpcontent/uploads/2014/07/Risk_thematic_final_web.pdf (accessed 26 May 2015).

Prisons and Probation Ombudsman (2015) Learning from PPO Investigations: Self-inflicted Deaths of Prisoners - 2013/14. Available at: http://www.ppo.gov.uk/wp-content/uploads/ 2014/07/ACCT_thematic_final_web.pdf (accessed 26 May 2015).

Schindeler, E. (2014) 'Workplace violence: extending the boundaries of criminology', Theoretical Criminology, 18(3), 371-85.

Shaw, J., Appleby, L. and Baker, D. (1999) Safer Prisons: A National Study of Prison Suicides, London: Department of Health.

Singh Bhui, H. (2007) 'Alien experience: foreign national prisoners after the deportation crisis', Probation Journal, 54, 376-7. 